\title{
At the Nexus between the National and the Global: The Discursive Construction of the Turkish Halal Market in the Neoliberal Age
}

Yesim Kaptan

Kent State University

Follow this and additional works at: https://digitalcommons.uri.edu/mgdr

Part of the Anthropology Commons, Critical and Cultural Studies Commons, Economics Commons, International and Intercultural Communication Commons, Marketing Commons, Mass Communication Commons, Other Business Commons, and the Sociology Commons

\section{Recommended Citation}

Kaptan, Yesim (2019) "At the Nexus between the National and the Global: The Discursive Construction of the Turkish Halal Market in the Neoliberal Age," Markets, Globalization \& Development Review. Vol. 4: No. 1, Article 5. DOI: 10.23860/MGDR-2019-04-01-05

Available at: https://digitalcommons.uri.edu/mgdr/vol4/iss1/5

This Article is brought to you for free and open access by DigitalCommons@URI. It has been accepted for inclusion in Markets, Globalization \& Development Review by an authorized editor of DigitalCommons@URI. For more information, please contact digitalcommons-group@uri.edu. 
At the Nexus between the National and the Global: The Discursive Construction of the Turkish Halal Market in the Neoliberal Age

\section{Markets, Globalization \& Development Review}
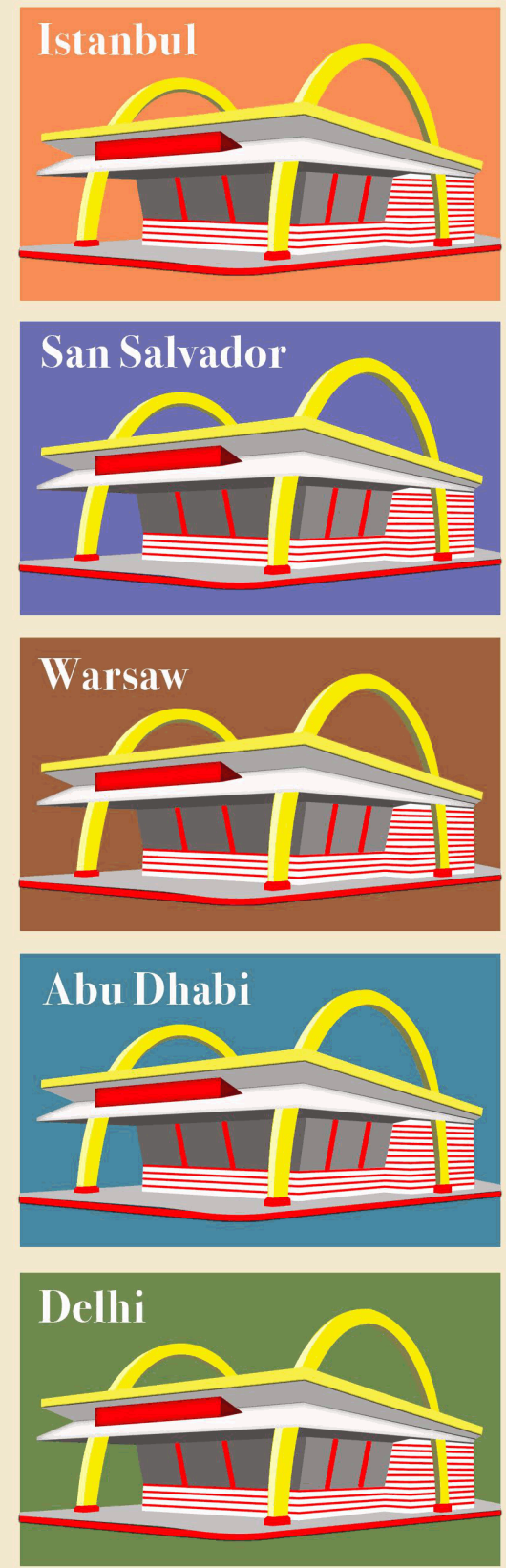
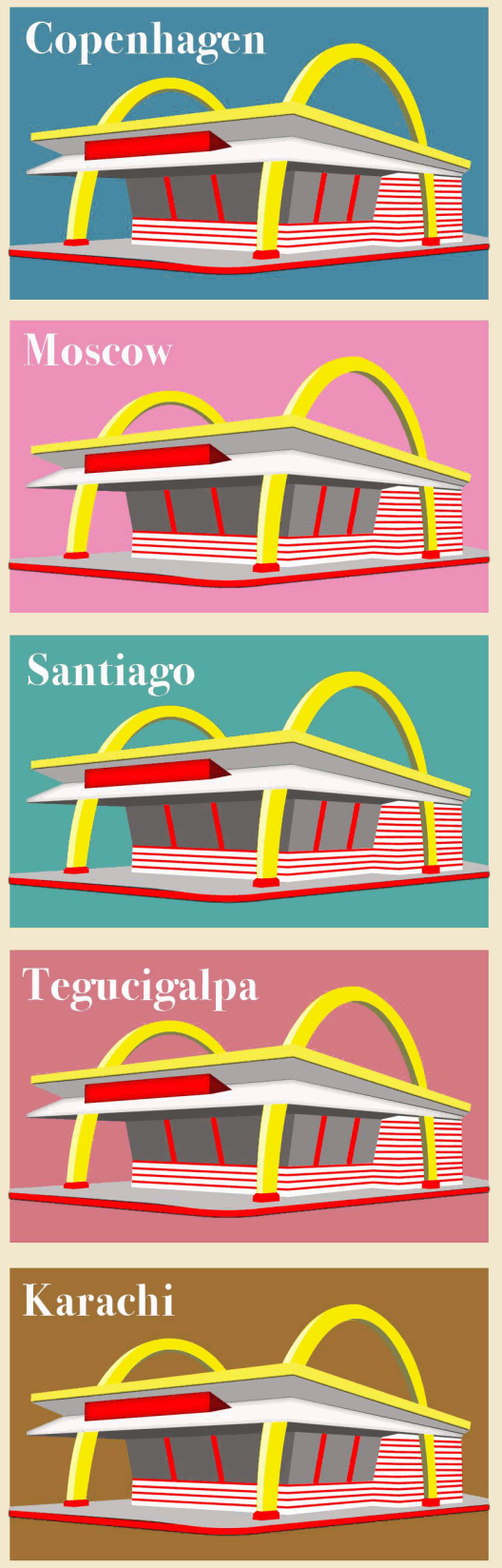
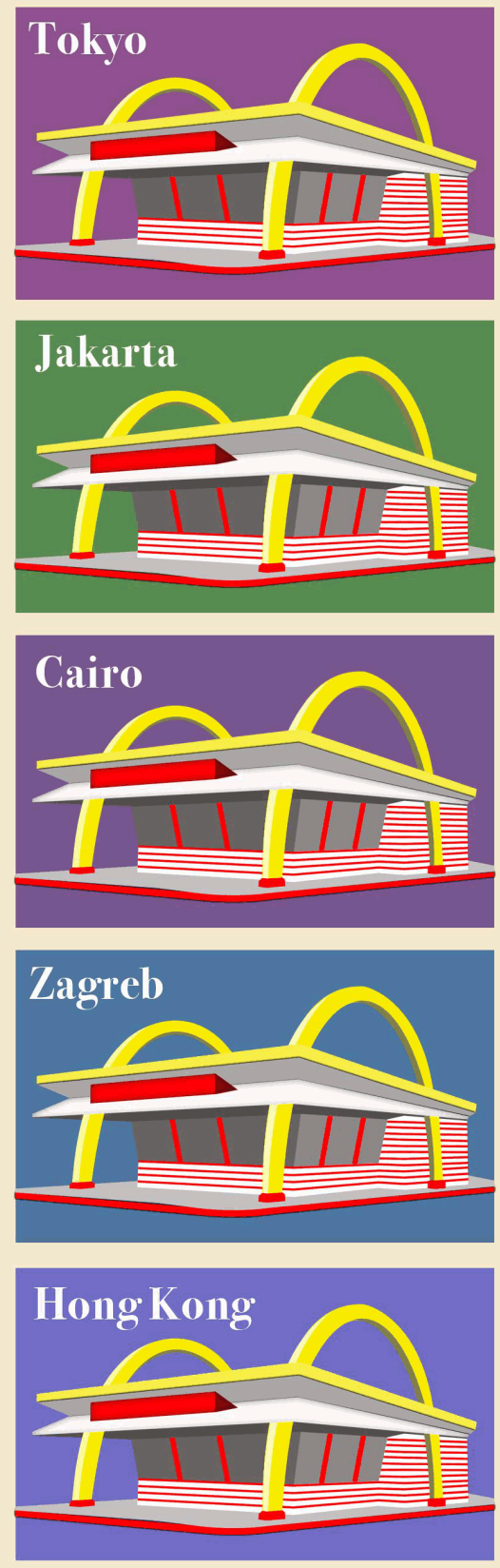

This article is available in Markets, Globalization \& Development Review: https://digitalcommons.uri.edu/mgdr/vol4/ 


\section{At the Nexus between the National and the Global: The Discursive Construction of the Turkish Halal Market in the Neoliberal Age}

\section{Introduction}

The global halal market is estimated to be worth $\$ 632$ billion (USD) a year and is one the fastest growing markets in the world (Bergeaud-Blacker, Fischer, and Lever 2016). The certification of halal products and services has become a significant marketing practice in some non-Islamic countries (Fischer 2011), especially in the 1990s. However, until recently, certifying halal goods in a Muslim country such as Turkey has been considerably less common. During the 2000s, some private Turkish companies began to distribute halal certificates issued by international institutions based in Malaysia, Iran, and Indonesia. Turkish entities serving as agents of the certification institutes initiated halal certification as a business. To regulate this profitable market, a state regulatory institution, the Turkish Standards Institution (TSI) began to issue its own halal certificates in 2011. The Turkish Standards Institution claimed sole authority to award halal product certification to halal producers and shops. This state power-grab provoked heated controversy in the Turkish halal market. The conflict revolved around legitimacy and religiosity of halal certification institutions ( $\mathrm{HCls})$. Since then, many private regulatory bodies have entered the halal market, resulting in fierce competition.

This paper focuses on analyzing discourses of the official websites of three HCls, The Food Auditing and Certification Research Association (GIMDES), Halal Food Auditing and Certification Center (HEDEM), and Health, Security and Halal Association (HELALDER), during the establishment of halal market as an emerging field in the time period of the rise of neoliberalism and political Islam in Turkey. Relying on Pierre Bourdieu's definition of the field, this study strives to answer two research questions:

R1: How do HCls utilize different discursive strategies in order to differentiate from their rivals, to achieve legitimacy and recognition and to acquire power in the halal market field in Turkey?

R2: How do Islamic actors ( $\mathrm{HCls})$ contest to construct the field of halal market including its rules and knowledge in an economy in which logics of neoliberalism and Islam operate hand in hand?

In this context, I identify three distinct strategies performed within the Turkish halal market: 1) claiming relative autonomy in an ambiguous 
position between national and global market fields, 2) defining politics of halal-ness through promoting symbolic consumption and producing Islamic knowledge, and 3) disseminating Islamic education through new cultural intermediaries. Analyzing dominant discourses of the Islamic actors, their appropriation, contestations, and the ways they constitute these discursive practices help us to shed light on previously overlooked and understudied relational positions and discursive formations of the Turkish halal market as a new field.

Recently, critical business studies scholars, anthropologists, and business administration researchers have studied the politics and economics of global halal markets (Ab Talib, Chic, Fischer 2017; BergeaudBlacker 2016; Bergeaud-Blacker, Fischer and Lever 2016; Fischer 2009; Bergeaud-Blacker 2004). In the last decade, neoliberalism, rapid globalization, and information technologies have drastically changed the landscape of Islamic markets. Sandıkçı and Ger (2001: 146) state, "Today's Islamic consumptionscape is characterized by pluralism and difference, and cannot be explained as either a rejection of consumerism, capitalism, or globalization or resistance to modernity." Accordingly, the growing number of halal goods and services demonstrate how Muslims have increasingly become the object of global and national commercial interests. BergeaudBlacker (2016) states that, particularly in Southeast Asia, halal markets are instruments for economic development in Muslim countries. Quite the opposite is true in some Muslim majority countries where everything is deemed to be halal. As Bergeaud-Blacker (2016) argues, the structural characteristics of the markets, the relationship between nation states and religion, the Islamic activism in different organizations, and the visibility of Islam in the public sphere play an important role in the plurality and complexity of halal markets in local and global economics. Despite its Muslim majority population, Turkey is one the countries in which concerns over halal standards and certification have emerged lately. Although some contemporary scholars discuss dependence between the fields of economics and religion in the Turkish halal market, these scholars exclusively focus on specific market divisions such as agriculture (AtalanHelicke 2015), meat and poultry (Lever and Anil 2016), tourism (Akyol and Kılınç 2014), Muslim consumers (Yener, 2015; Sandikci and Ger, 2007, 2001), or local practices of transnational corporations (Izberk-Bilgin and Nakata 2016). Fewer of these studies examine the discursive formations of the halal market (Atalan-Helicke 2015; Izberk-Bilgin 2012). These researchers have made significant contributions to understanding the intersection of Islam and capitalist market economy. However, my own exploration contributes to the literature by applying Boudieusian perspective 
to the local Turkish halal market in combination with the critical discourse analysis which will yield an understanding of this market as an emerging field. Drawing on the discursive strategies of HCls, analysis of the Turkish halal market where $\mathrm{HCls}$ and other actors (the state and businesses) strive to define the rules presents a field formed by the politics of contestation of multiple discourses. I employ critical discourse analysis to unravel power structures embedded in discourses by $\mathrm{HCls}$ and meanings communicated through the language of new media. The theoretical framework of the field theory of Pierre Bourdieu is particularly useful in the context of the Turkish halal market because it facilitates analysis of "the positions of the field visà-vis the field of power" and mapping of "the objective structures of relations between the positions occupied by the agents or institutions who compete for the legitimate forms of specific authority of which this field is a site" (Bourdieu and Wacquant, 1992: 104). Field theory locates social actors and the networks between them in a historically shaped field of power and competition (Swartz, 1997).

In this study, first, I explore the theoretical framework: Bourdieu's concept of field and field theory. Second, to fully develop the concept of the Turkish halal market as a field, I include in-depth examination of the sociopolitical context of Turkish institutions and investigate significant nexus between Islam, secularism, and neoliberalism in Turkey. Before analyzing the organization of Islamic halal-certification bodies, I briefly discuss the rise of Islamic bourgeoisie in recent years in Turkey. Third, I explain the data collection and the method of the study. Fourth, I focus on specific discursive strategies of three prominent actors of the Turkish halal market. These strategies vary from claiming relative autonomy and marketization of symbolic products such as halal champagne and wine to debates on knowledge production and Islamic education. In the final section, regarding halal market as a symbolic mode of communication, I conclude that Turkish halal certification actors are simultaneously adapting, appropriating, and contesting Islamic discourses for justification of their existence and acquiring power in the formation and transformation of the emerging field of the Turkish halal market in the global neoliberal economy.

\section{Theoretical Framework: Field Theory}

According to Bourdieu (1983; 2005), practices occur in structured arenas of conflict called fields. In other words, fields mediate the relationship between social structure and cultural practices (Swartz, 1997: 9). Bourdieu defines a field as "a network or configuration of objective relations between [social] positions" (Bourdieu and Wacquant, 1992: 99). Field, or the social space (Bourdieu, 2005) in which configurations and interactions happen, is a 
significant aspect of Bourdieu's work, and a useful operational concept in research. An analysis of social space not only locates the object of investigation in its specific historical and local, national, international, and relational context, but it also interrogates the ways in which previous knowledge about the object under investigation have been generated, by whom, and whose interests were served by those knowledge-generation practices.

Üstüner and Thompson (2012: 799) state that "accordingly, the logic of field analysis has been applied to many different levels of social aggregation, ranging from macro-level systems of sociocultural practice (e.g., the economic field, the field of cultural production, the field of consumption); specific organizational domains (e.g., the journalistic field, the academic field, the nursing field, and the field of medical education); and still more contextually circumscribed institutional spaces such as the field of the [i.e] museum." In this study, I conceptualize the "field" of halal market as a semi-autonomous mezzolevel organizational sphere in which social interactions, events, economic transactions, individual actions, discursive power struggles, and competition for recognition occur. The halal market simultaneously occupies multiple social fields including the economic field, the field of religion, the bureaucratic and political fields, and the cultural field. Thomson (2014: 70) claims that "Bourdieu posited a social world (the field of power) made up of multiple fields: large fields could be divided into subfields (e.g. art into literature, painting and photography)." She adds that "to complicate things further, Bourdieu suggested that the institutions within fields also operated as subfields, and his analysis of the housing market exemplifies both an analysis of the field, and the subfields of specific housing firms" (Thomson, 2014: 71). In a similar vein, by taking Bourdieu's field approach into account, I explore HCls as a subfield within the field of halal market.

Field theory is concerned with the relationship between macrostructures of power and organizational and professional practices of the actors in the field. Bourdieu (2003) considers a field as a dynamic site of struggle among social actors. This struggle in the field are mainly connected to power and status. Metaphorically speaking, Bourdieu suggests that his notion of the field resembles a game. Similar to a game, every field establishes its own structure of relations, governs the field by its rules and regulations, creates respective positions of agents, and constitutes its valued forms of capital (Üstüner and Thompson, 2012: 799).

Bourdieau's field perspective differs from sociological analysis of contemporaries that limits power to the control of resources. Bourdieu's fields are "arenas of struggle not only for control over valued resources, but 
also for legitimation" (Swartz, 1997:122-123). The strategies in the struggle for power are related to legitimation and recognition of one's position in the given field. Swartz says, "Indeed, for Bourdieu power is not a separate domain of study but stands at the hearth of all social life. And the successful exercise of power requires legitimation" (Swartz, 1997: 6). Therefore, Bourdieu considers all field structures to be are "arenas of struggle for legitimation" (Swartz, 1997: 123) as well as "fields of knowledge" (Thomson, 2014: 66).

In this context, Bourdieu's conceptualization of field proves well suited for analyzing the newly emerging Turkish halal market. The halal market emerges as a discursive field in which $\mathrm{HCls}$ are located in inter-field dynamics of the fields of economics, religion, politics, and cultural production. Application of field theory reveals the contested and conflictual character of the halal market as an arena of struggle for legitimation and power in a religiously oriented market. Bourdieu's sociological theory and his conceptualizations including the field are particularly significant to a fuller understanding of discursive practices of $\mathrm{HCls}$ in a relational context and historical social space which highlights the relationships between the Islamic religion and the social structure of the market. To understand the Turkish halal market as an emerging field, first, I look at how the halal market operates in a neoliberal global order in the broader historical and socio-political context of Turkey.

\section{Contestations of Turkish Halal Market: Secular Modern Turkey, Islamic Bourgeoisie, and Neoliberalism in a growing Field}

During the 1920s and 1930s, the founding fathers of the modern Turkish Republic transformed Turkey by implementing rigorous westernizing reform policies. Mustafa Kemal Ataturk led Turkish elites in a modernization project to transform Turkey from a multi-religious and multi-ethnic Islamic state to a secular nation state. According to Navaro-Yashin (2002a), secularism has long defined the state in Turkey. Even today, secularism is one of the fundamental, yet the most controversial, pillars of the modern Republic. Some Islamist groups have represented themselves as anti-secular. These groups lead movements that inspire sentiments against Western lifestyle, traditions, and values. At the discursive level, the relationship of these Islamic groups with modernization and western commodity cultures has been perceived as critical (Navaro-Yashin, 2002b; Gülalp, 1997; Göle, 1997). 
Navaro-Yashin (2002b: 222) argues that "politics of culture between secularists and Islamists in Turkey in the 1980s and 1990s developed in the context of a consumer market influenced by globalization. So central was consumerism to the social life of this period that political conflicts were organized, expressed, and mediated through this medium." As noted by Navaro-Yashin (2002a; 2002b) and Nilüfer Göle (1997), in Turkey, the relationship between Islamists and Western modernity is a crucial, yet deep and complicated one. Commodification and social practices of modernity have infiltrated Islamic communities and left their mark on both Islamic and secular communities (Sandıkçı and Ger, 2001; 2007).

This relationship has become even more complicated with Turkey's shift to neoliberalism and its engagement with rapid globalization through transnational networks. Until 1978, the Turkish economy was characterized by an import-substitution regime and the state was the key player for the regulation, the development, and the growth of the economy (Öniş, 1998). According to Öniş, in the 1980s, "a profound shift in philosophy occurred in Turkey concerning the role of the state in economic affairs. The new economic strategy aimed at decreasing both the scale of public sector activity as well as the degree of state intervention in the operation of the market" (1998: 183) through liberalization and extensive privatization. However, this does not rule out "the complexity of Turkey's recent political economy [which] relates to the apparently contradictory trends involving centralization and decentralization simultaneously" (Öniş, 1998: 189).

After the 1980s, conservative Islamic businesses and religious sects, previously excluded from and marginalized in economic landscape, were incorporated into the Turkish national economy (Izberk-Bilgin, 2012; Öniş, 1998). The neoliberal incentives of the ruling Adalet ve Kalkinma Partisi (AKP) (Justice and Development Party) eased the way for the rise of an Islamic bourgeoisie in provincial towns and cities of rural Anatolia as well as in cosmopolitan centers of Turkey (Atalan-Helicke, 2015; Sandıkçı and Ger, 2007). Izberk-Bilgin (2012: 44) argues, "the prominently secular façade of the Turkish marketplace significantly changed with the proliferation of faithbased offering such as Islamic media, movies, music, novels, toys, swimsuits, resorts, beauty shops, and cafes in the 1990s." In the 2000s, according to Sandıkçı and Ger (2007: 189, 210), for the neo-Islamic bourgeoisie becoming modern is the utmost concern since the modern identity signifies the integration with the global world. Together the neoIslamic middle class and Islamic businesses fostered by AKP policies support and aid the halal market movement. As I discuss in the next section, during the 2000s, Turkey has taken a shifting position in relation to Islam by 
attempting to represent both the global and the local geopolitical power configurations.

\section{Turkey: Centralization of Authority, Decentralization of the Halal Market}

Since AKP came to power in 2002, Turkey has strived to become a global player in the economy and the world politics. In the early period of AKP rule, the Islamic government has concentrated on improving political, economic, and cultural relationships with neighboring countries in the Middle East as well as with the Islamic states to hold a prominent position in the Muslim world (Kaptan and Karanfil 2013). This vision shaped country's foreign politics and fulfilled in the President Recep Tayyip Erdoğan's ambitious actions and statements until recently. For example, Turkey hosted the recent Organization of Islamic Cooperation (OIC) summit in April 2016. Erdoğan has been elected as the current chief of the organization (OIC). Erdoğan's ambition to be a global leader of the Muslim world has resurfaced in many populist occasions including condemning Myanmar's attitude towards Muslim minorities (Rohingyas), supporting Syrian opposition against Assad's regime, criticizing Sisi's coup d'etat in Egypt at the 69th United Nation General Assembly after the fall of the Islamist Morsi Government, and clashing with Israeli president Shimon Peres over Palestinian issues and Gaza in a World Economic Forum debate in Davos.

Surprisingly, Turkey has not claimed any leadership in the global halal market and has not entered into a fierce competition with other Muslim countries to regulate the world halal trade while the country strives to take a prominent role in the Muslim world. In correspondence with its neoliberal economic strategies, the AKP government hangs onto the idea of retreating states particularly in the Turkish halal market. Unlike in Malaysia and Singapore (Fischer 2011), the Turkish state has neither introduced nor strictly enforced standardization in the halal market. The state has become one of the economic actors among many in the Turkish halal market. In the global neoliberal logic of the economy, by abolishing its authority to regulate the faith-based market and avoiding to implement rules of standardization, the Turkish state paved the way for a market halal field run by the private companies.

\section{Methodology and Data Collection}

The field theory is concerned with "how meaning is produced relationally, both via the play of difference among symbols and among the social agents who produce them" (Benson, 1998: 486). According to Swartz field analysis 
"directs the researcher's attention to a level of analysis capable of revealing the integrating logic of competition between opposing viewpoints. It encourages the researcher to seek out sources of conflict in a given domain, relate that conflict to the broader areas of ... power, and identify underlying shared assumptions by opposing parties" (1997: 126). In this regard, field theory scrutinizes the positions of the institutions, organizations, groups, and individuals within the societal power structure while taking particular historical development of a national culture into consideration.

In this study, I utilize field theory as an epistemological approach rather than a methodological approach. Field theory provides us the structural locations of the agents within a specific field. Each agent claims a position in the field in relation to other agents regarding its autonomy and heterenomy. From a Bourdieusian perspective, field theory investigates power struggles shaped by different forms of discourses for the construction of social reality, which is constituted by an ongoing struggle over meaning. In addition, for Bourdieu, relational thinking is an important concept since subjects (persons or institutes) derive their social meaning from their positions with respect to one another in a social field (de Nooy, 2003: 305). Therefore, here, I take into consideration the discursive positionality of the $\mathrm{HCls}$ not only regarding their discourse of autonomy and heteronomy, but also the shifting power dynamics between the global and national halal markets. In the field theory, both the position and power of each particular agent is determined by the specific rules of the field and interactions among the agents. David Swartz (2016) states that "the concept of field stands as an alternative analytical tool to institutions, organizations, markets, individuals, and groups, though all of these can be key components of fields. Field analysis brings these separate units into a broader perspective that stresses their relational properties rather than their intrinsic features and therefore the multiplicity of forces shaping the behavior of each." Field analysis provides a broader perspective to indicate the halal market discourse as a structured totality created by relational positions of Islamic agents. However, methodologically, I will employ critical discourse analysis to explore the websites of HCls.

Canniford and Karababa (2013) emphasize the importance of discourse in the construction of a marketplace through ambiguous and malleable articulations and changing configurations of social actors in contemporary consumer cultures. The concept of halal, which has been defined "culturally and economically," (Bergeaud-Blacker, Fischer and Lever, 2016) has also been determined through discursive formations with regard to power relations in local and global markets. 
Critical discourse analysis (CDA) has been developed as an interdisciplinary approach to study language and relations between discourse and power in different socio-cultural contexts. Methodologically, the discourse analysis is grounded in a rigorous and detailed linguistic analysis of texts (Phelan and Dahlberg, 2011: 9). However, similar to field analysis, CDA focuses on contested meanings of opposing parties or competitors in order to reveal the concealed logic of mechanisms of power. Both field analysis and CDA investigates naturalization processes of the dominant belief systems, and how actors and agents contribute to the maintenance of the power relations and social order. Particularly, through the analysis of linguistic structures, CDA can explain overt relations of struggle and conflict (Wodak, 2001:2) in social structures. In a similar vein, Bourdieu theorizes "fields as antagonistic, as sites of struggles" (Thomson, 2014: 78). In this research, field theory delivers a macro analysis for understanding the social reality constructed through discursive practices of the $\mathrm{HCls}$, whereas CDA provides a methodology that offers an elaborate linguistic analysis of the written texts-the websites of $\mathrm{HCls}$.

Considering discourse as a form of social practice, this paper carries out a critical discourse analysis of websites of halal regulatory institutions by focusing on the ways in which language is in use. To identify the controversies and prominent topics of halal discussion, the data was collected between May 1, 2015 and January 30, 2016 from websites of three vanguards of Turkish halal sector: GIMDES, HELALDER and HEDEM. In a complex material of media, the study selectively draws data from their bi-monthly trade magazines, editorials, statements of mission and vision, and other founding documents to analyze discursive strategies of the $\mathrm{HCls}$ in an emerging field. In order to find related media texts, I used search engines of these websites. Through their digital archives, I searched for related discourse strands regarding "halal," "halalness," and "haram" (unlawful). To define their strategies, I investigate the linguistic features including lexical choices, grammatical structures, cohesion, and semantics. All texts were read carefully to determine reiterating narrative patterns, repeated words, contested phrases, and recurrent content. I particularly selected articles and editorials which discusses the politics of definition of "halal" and "halalness" and those which deals exclusively with the field of power. A total of 43 media texts were selected in aforementioned websites. Among 43 texts, particularly 15 articles and editorials have been chosen for detailed linguistic analysis as representative of discourses about politics of defining halal. First, I specifically looked at the articles and editorials which could be associated with broader fields of religion, culture, and halal economy and stand at the intersection of these fields. I read all articles one- 
by-one and noted repeated ideas and concepts in order to create conceptual groups. Conceptual groups were divided into sub-categories based on common themes including autonomy-heteronomy; symbolism; knowledge production, and instruction. I took into account the categories appeared multiple times in the given time period by grouping them into three main categories: the discourse of (1) relative autonomy at the nexus between the national and the global market fields, (2) symbolic consumption and Islamic knowledge regarding the definition of halal and halal-ness, and (3) Islamic education provided by $\mathrm{HCls}$ as new cultural intermediaries. Finally, all media materials were re-read to reorganize and to eliminate overlapping categories.

\section{The Emergence of Halal Market in Turkey}

The halal market, first, has emerged de facto without any official regulations by the state. Customarily, self-certifying companies, working with local clerics (imams), developed a self-motivated and self-driven halal industry particularly in the poultry and the meat sector (Lever and Anil 2016). However, "the greater rise of halal awareness in Turkey can be traced back to 2002 when the ruling AKP came to power and re-legitimized Islam" (Lever and Anil, 2016: 43). In the 2000s, the private halal certification institutions such as GIMDES, HEDEM, and HELALDER aggressively entered the market to regulate halal industry in Turkey.

GIMDES, the first for-profit halal certification institution in Turkey, was established in Istanbul in 2005. According to Izberk-Bilgin, GiMDES is "a noteworthy example to the Islamist activists' space-making for and discursive formation of a new market within a prominently secular marketplace with little halal consciousness" (Izberk-Bilgin, 2012: 46). It plays a vital role as it offers a wide range of training and educational programs, various international conferences, exhibitions, fairs and workshops that complement the ambitious strategies aimed at raising the public awareness of the principles and concepts of halal and the importance of halal certified products. The variety of accredited institutions with which GIMDES works in many continents including Australia, Europe, and Asia reflects the global nature and prevalence of halal business as well as company identity of GIMDES. In this study, among three institutions, GIMDES has received prominent attention due to its well-recognized market dominance (Atalan-Helicke 2015; Izberk-Bilgin 2012) in the Turkish halal economy.

In 2010, two non-governmental institutions, HEDEM and HELALDER, emerge as rivals to GIMDES in order to regulate the national halal industry. HEDEM was founded in İstanbul to "provide awareness to 
Muslim consumers in the fields of food, cosmetics, medical, and cleaning supplies (HEDEM Icerik 2015). In addition to its high level integration with the Western institutions, HEDEM works in cooperation with the international certification bodies in Latin American countries and East Asian institutions. Since its establishment, HEDEM has taken a different position in the halal market field. Unlike GiMDES, the regulatory body acts as a halal education academy for inspectors of halal market.

Based in Konya, HELALDER was established with the aim of "facilitating the supply of halal food, carrying out studies on halal products, and providing certification for halal goods" (Helalder Kurumsal 2015). The certifying body mostly worked with local companies and collaborate with Baharu Corporation that specializes in importing and distributing various products in Japan. In addition to Turkey, they distribute certification for halal products mainly in Japan and Jordan. Although it came to halal movement as an early player, HELALDER remained relatively less competitive and more peripheral in the industry. Hence, my analyses mainly revolve around GIMDES and HEDEM.

\section{Discourse Analysis and Websites of the Turkish Halal Bodies}

The relative autonomy and the secular nation state

Among all recent policies of AKP government, the Turkish halal certification bodies have most benefited from the deregulation of markets principle of neoliberalism, since deregulation offers new possibilities in business via multiplicity of discourses in the market. Under the pro-Islam and neoliberal AKP government, the changing definition of Islamic consumption through incorporation and negotiation with neoliberalism has become a significant strategy for Islamic halal-certification organizations. Their discursive strategies have been manifested on the discourse of the relative autonomy which challenges the authority of the nation state. Since the Turkish state restructures the halal market field by embracing decentralized tendencies, the autonomy of the halal market field and specifically relative autonomy of the $\mathrm{HCls}$ become one of the dominant discourses in the field. The Turkish state has become one of the economic actors in the halal market field by giving up its major role as a regulatory institution which governs the Turkish halal industry. Thus, $\mathrm{HCls}$ would be in a position to exploit halal market and would bypass state's authority. Local institutions are able to form alliances with global actors of halal market and global halal regulatory bodies of different nation states other than their own. For instance, the life-long tension between secular modern state and Islamic agents has become evident in GIMDES' identification of "halal" and in its effort for legitimacy of 
their halal certification accredited by JAKIM of Malaysia. In an interview, the founder and the president of GIMDES, Hüseyin Kami Büyüközer states that "We are issuing [halal] certificates based on Malaysian [government's] [halal] standards [because] a halal certification, issued by a secular government, is unacceptable. [Halal] standards of TSI [of the Turkish government] is originated $99 \%$ in the West. Such an institution cannot distinguish halal from haram (unlawful)" (Sabah 2011). In this statement, Büyüközer not only challenges the power of secular Turkish state and questions the religiosity of the state's certification institution (TSI), but also legitimizes GIMDES' existence as imperative. The authority and power of the modern state in the national economy has come under scrutiny when GIMDES searches for autonomy in a global scale against the nation state. In addition, by discursively aligning GIMDES with the heteronomous structures of transnational halal market field, Büyüközer creates an image for GIMDES in the field of power in the halal market. By implicitly stating the relative autonomy of his institution, he highlights GiMDES' ability to work with another Islamic nation state and with a transnational halal regulatory body more efficiently than the national institutions.

The struggle for legitimacy and the institutional authority is more striking in terms of antagonisms between GIMDES and TSI when Büyüközer uses a subversive discourse and rejects the legitimacy of TSl's certification of halal. He harshly criticizes the religiosity of the modern secular state for competing in the halal market field. Rather, he emphasizes the legitimacy of the Islamic transnational regulatory bodies that are known for their heteronomy. Büyüközer implies for the need for an Islamic autonomous halal market that exceeds the nation state's authority.

Symbolic consumption and Islamic knowledge: Case of halal wine and champagne

Creating an Islamic market field concerns the circulation of Islamic knowledge about products and practices and of what is Islamic and what is not. In a context wherein Islamic knowledge is considered a primary and superior form of knowledge, greater leverage and power are gained by institutions of certification. Nevertheless, the discourses of certification institutions have brought about increased complexity and multiplicity of contested Islamic knowledge and symbolic consumption. For some Muslim consumers, halal wine and champagne have become an economically and culturally relevant and religiously appropriate product within the field of economy while others strongly reject and resist to these products and the marketing idea in the field of religion. Therefore, the discourse of the certification bodies about the diverse nature of the halal concept regarding 
the issue of non-alcoholic halal drinks, such as halal wine and champagne has become a discursive battle field for defining halal.

As part of their marketing strategy, some halal-certification bodies provide certifications for companies that enter new markets with Muslim consumers and compete in the global alcoholic beverage industry. Mostly, non-alcoholic wines contain 0.2-0.5\% alcohol. However, a European based company called Kevser Tabak claims that the company eliminated alcohol completely in its wine-making process (Ziauddin 2013). Taner Tabak, a Turkish-Dutch businessman who produces halal champagne and wine under the brand name Kevser explains how the idea of halal wine was born: "In a reception for businessmen living in the Netherlands, a Muslim businessman complained about non-alcoholic beverages and asked why there were no alternative for Muslims who cannot consume alcohol. Referring to the wine being served, he said, 'I wish there were halal versions of this, then we would drink it"' (Milliyet 2015). In this statement, Tabak implies that an affluent Muslim who has a right and an opportunity to attend upscale receptions also has a right to consume halal wine. By the same reasoning, any Muslim, not just the wealthy ones, should not be deprived of consuming a highly symbolic and hedonic product. Wine is a significant product due to its religious connotations in Christianity and is a symbolic marker of social class (Bourdieu 1989). Tabak claims that there is high demand for their products, especially for halal champagne in Turkey, Germany, and the Netherlands. Kevser is certified by HQC (Halal Quality Control) agency, based in the Netherlands.

Although some certification institutions promote halal wine and champagne, other organizations, like GIMDES, accuse such companies of "being ungracious" and use unrestrained, emotive, and very direct language on their websites, as evidenced in an article in GiMDES's website: "Inglorious [people] are on duty: Halal Champagne! ... Since Christmas is approaching, to influence [literal translation: to "infect"] Muslims with their disgusting lives, [infidels] are trying to implement various plans of the devil .... These infidels (kefereler) never give up cooperating with the devil to make Muslims sinners" (Gimdes 2015e). GiMDES claims that the institution that certified Halal champagne has not been recognized internationally in the halal market. However, as discussed above, in case of GIMDES, Büyüközer underlines global collaborations of his company with global halal regulatory bodies such as JAKIM of Malaysia. The contradiction in Büyüközer's statement exemplifies the power struggles in the halal market field which attempts to provide legitimacy to GiMDES over other halal certification bodies. GIMDES president Büyüközer gives his views on halal non-alcoholic drinks, stating that "this is devilishly cunning." For Büyüközer, 
these are tricks of non-Muslims to deceive believers and lure them to drinking non-alcoholic wine that will later spiral into consumption of the alcoholic version (GIMDES 2015a). Here, his discourse is connected with the symbolic significance of halal drinks. Halal wine and champagne acquire a sign commodity status in the symbolic network of halal goods by providing alternatives for Muslim consumers. In a global economy marked by nonIslamic practices, GIMDES challenges not the modes of symbolic consumption but the dominance of haram products and ingredients in goods. In the process of commodification, providing halal wine and champagne in line with Islamic rules has no utility value, but represents a symbolic referent for differentiating and branding an identity for the Islamic consumption culture. The halal products posit a discussion wrapped around symbolic referents of culture and religion. Producing halal wine and champagne is a symbolic attempt, as well as a profit driven effort, which offers a lifestyle experience to Muslims faced with an enormous range and diversity of alcoholic products. Halal wine or champagne, which has a symbolic meaning and a religious connotation, has become an object of prestige for Muslims who have adopted the consumption patterns of modern and secular Western lifestyles. Therefore, the paradox arises the juxtaposition of opposing elements through a discussion of seemingly contradictory products, such as halal champagne and wine.

In a similar debate, halal-certification institutions discuss the use of alcohol not only in drinks but also in mundane products that Muslims consume. However, this also becomes a controversial issue among $\mathrm{HCls}$, which exhibit varying attitudes to rules governing Muslim life. HCls do not provide a uniform approach to Muslims. In particular, GIMDES raises concerns about alcohol in medicine and cosmetic products. In its websites, GIMDES declares the following statement: "Many hospitals and pharmacies provide cough syrups that contain about $60 \mathrm{mg}$ of alcohol and even mention this fact on their bottles. Will the Muslim use this syrup? Do they not have a right to ask for cough syrup without alcohol?" (GIMDES 2015b).

Despite the objection of GIMDES, both HEDEM and HELALDER defend Muslims' right to consume alcohol in health and cosmetic products for daily use. Here, HEDEM and HELALDER give an example of the power struggle to produce legitimate knowledge about the knowledge of religion and halal lifestyle. As opposed to emotionally reactive approach of GIMDES, HEDEM (Helal Denetim 2015) takes a didactic position and states that:

In case of treatment, there are two different approaches to halal. Based on the Prophet's saying, 'God has not declared your remedy in haram' (Allah şifanızı, size haram kıldığı 
şeylerde kılmadı)' (Buhari, K.el-Eşribe: 15), any medication or drug considered haram is forbidden. Another approach claims that although the Prophet Mohammed forbade men to wear silk, he gave permission for some of his companions to wear it if they suffered from a skin disease (Buhari el-Libas, 29;K. El-cihat,91). By the same reasoning, if there is no halal medication for a specific treatment, haram drugs are considered licit [including those containing alcohol].

On the contrary, HELALDER enters the debate with a bold statement: any alcoholic drink is strictly forbidden and is explicitly haram. However, in the cosmetics industry, use of alcohol is permitted within the limits of the Ministry of Health (Alkol Konusunda Fetva 2015). In contested debates about halal wine, champagne, and mundane products that contain alcohol, the conflicting and contradictory discourses of halal bodies have made the definition of "halal" even more ambiguous. As a result, the conceptualization of halal has become more open to question. The multiplicity of dispersed and disconnected definitions has brought about a lack of coherence and diverse approaches to halal. However, this approach has also provided an opportunity for halal-certification bodies to develop and flourish in an ambiguously defined and vaguely structured market to legitimize their existence and to facilitate their power to generate knowledge of an emerging field.

Consequently, given the complex nature of the halal concept, these bodies make claims regarding the greater validity of their own certificate in comparison with others. The symbolic boundaries of what is halal and what is haram are not determined solely based on religious scripts, the Koran, traditional norms, or normative conventions. Therefore, the $\mathrm{HCls}$ negotiate, reappropriate, and adapt these boundaries and coordinate the social interactions among competitors. In the field of halal market, knowledge of halal is negotiated and disputed to create a criteria of legitimacy of Islamic actors through antagonistic discursive struggles. The legitimization for the existence of $\mathrm{HCls}$ depends routine confirmation of this legitimacy and socioeconomic hierarchy on a regular basis. In the next section, I show how discussions among organizations indicate these institutions' approaches to education as well as their struggles in the field for the legitimacy and power.

The new cultural intermediaries, and educating Muslims

Bourdieu (1984) describe "new cultural intermediaries" as groups of workers involved in the provision of symbolic goods and services. According to Bourdieu (1984), the main purpose of new cultural intermediaries is 
production, dissemination, and marketing of symbolic goods. In the Turkish halal market, Islamic certification institutions strive to play a leading role as "new cultural intermediaries" whose mission is to educate the Muslim publics on halal consumption and Islamic lifestyle. Training Muslims about halal consumption is one of the strategies of $\mathrm{HCls}$ to perpetuate and advance their position among halal regulatory bodies. Benson (1998) states that in field theory, changes in the structure of fields are produced from two basic sources. Since "to exist in a field is 'to differ,' a 'dialectic of distinction' ensures the constant production of change as new actors attempt to enter and make their mark in the field" (Benson, 1998: 487). HEDEM particularly positions itself as a pedagogical intermediary and strives to construct a distinct identity in the halal marketplace. On its website, the President of HEDEM, Selahaddin Alıç, emphasizes that education and the dissemination of Islamic knowledge are among the main objectives of HEDEM. By embracing education in a broader sense, he says "reading and learning are swimming against the tide of ignorance" (Alıç 2016). In doing so, HEDEM strives to occupy a dominant position and to carry out a controlling ethos in the field of Islamic education. It searches for prestige and recognition in the halal market field by positioning itself as an educational cultural intermediary.

The founders of HEDEM also differentiate their institution by defining the identity of the founders as "the educated intellectual scholars of this country [Turkey]." Later, they explain their identities in detail: "We established this association because of our devotion to serving others as the elite and respected academics, literates, doctors, veterinarians, agronomists, chemists, engineers, and economists." The words "academics" and "literate and educated" were repeated in the text, capitalized, and colored red (Helal Denetim 2016). In doing so, HEDEM aims to create reconciliation and a balance between religious knowledge and scientific/intellectual knowledge. The discourse of HEDEM simultaneously represents a contested approach to education. In this respect, HEDEM and its stakeholders claim an ambiguous position, both as religious scholars and scientific intellectuals. By claiming scientific authority, as well as a possession of Islamic knowledge, HEDEM continues to instrumentalize the scientific and empirical approach originates not only from diverse discourses among halal-certification associations, but also from the inconsistency in the institution's expressions regarding education.

The function and mission of the halal-certification institutions range from the general education of uneducated masses, to the convergence of specific knowledge (about hygiene etc.) to the public. GiMDES explains its mission in terms of creating and organizing "Muslim consumers" and 
educate them about the products that they would consume (Halal Certification Turkey 2015). From this perspective, GIMDES situated education as a precondition of halal consumption. Educated and wellinformed Muslims identify and consume relevant halal products and services offered by Islamic cultural intermediaries. By employing pedagogical tools such as workshops, conferences, training programs, GIMDES strives to play a significant role in educating the public not only in Turkey but also worldwide. On their English website, GIMDES explains the aim of their pedagogy: "GIMDES, the leading Halal-certifying body in Turkey is organizing exhibitions and conferences every year to increase the public awareness of Halal Certified products. We are proudly announcing that this year we are organizing the international halal and tayyib workshops which will be held in Istanbul" (GIMDES 2015c). Based on titles of the papers presented in panels, the workshops focus on different aspects of Islamic lifestyle, including pharmaceuticals, cosmetics, halal tourism, and new updates in animal slaughter and stunning. GiMDES claims to contribute to the religious preservation of individuals and society as a whole (GIMDES 2015d). Here, GiMDES not only offers Muslims a practical training on halal and haram, but also competes with its rivals to generate and disseminate Islamic instructions which provide leverage to the company in the power play of the halal market field.

\section{Conclusion}

Until recently, the halal market which is supposed to be an Islamic practice was deemed unnecessary in many Islamic countries including Turkey. In this study, by focusing on the Turkish halal regulatory bodies GiMDES, HELALDER, and HEDEM I scrutinized discursive strategies of $\mathrm{HCls}$ and investigated how HCls negotiate legitimacy and power in the field of halal market and how the consecutive conflicts over contestation of discourses are undertaken in this field. I specifically discuss three main discursive strategies employed by the Islamic actors: 1) claiming a relative autonomy based on the ambiguous position of $\mathrm{HCls}$ between the national and the global market fields, 2) defining politics of halal-ness through symbolic consumption and production of Islamic knowledge, and 3) disseminating Islamic education as a liability of the new cultural intermediaries. I argued that Islamic actors are adapting, appropriating, and contesting marketing discourses for justification of their existence and acquiring power and legitimacy in a newly emerging, yet globally defined, national market field.

As a site of conflict and struggle, the halal market field emerges as a result of the coexistence of conflictual discourses. First, in order to monopolize power and legitimize its existence in the new field, every single 
institution attempts to universalize a particular interpretation of halal in Islam and strives to eliminate multiple and complex interpretations of other institutions. Each regulatory body mercilessly competes with other Islamic actors in the national halal market, but cooperate with transnational regulatory institutions. As a discursive strategy, aligning national halal regulatory bodies with the global certification companies and positioning $\mathrm{HCls}$ as relatively autonomous institutions at the nexus between the national and global fields play a pivotal role to achieve legitimacy and to seize power in the halal market. In this context, the decentralization tendency of neoliberal policies of the Turkish government, has created new opportunities for the relative autonomy and multiplicity of discourses of the Islamic HCls. The expeditiously growing Turkish halal market institutions have successfully aligned themselves with the neoliberal norms at the expense of religious ideology. $\mathrm{HCls}$ have reconfigured and calibrated religiosity to the extent that it has become commensurable with the tenets of neoliberalism. Second, in such a milieu, the halal market emerges as a field with an increasingly complex role of symbolic goods such as halal wine and champagne, and contested debates around the politics of the definition of halal. At the intersection of multiple fields including economy, politics, religion, and socio-cultural fields, $\mathrm{HCls}$ deviate halal market from other markets by positioning this field as a unique domain of Islamic knowledge production and symbolic consumption. Finally, the HCls contest to position themselves as the new cultural intermediaries of the field. In doing so, they facilitate the orientation of $\mathrm{HCls}$ in a global neoliberal market and communicate to inform Muslims about their authority in the field of halal market. Educating Muslims and creating halal demand is a pedagogical function of these organizations, which aim to create a new generation of Muslim consumers through marketing, thereby satisfying the needs of an expanding Islamic market as well as providing legitimacy for the rival institutions.

The emergence of halal market in Turkey is shaped and modified by country's historical and socio-economic circumstances. Even today, despite its large-scale development in the 2000s and the dominance of political Islam in the fields of economy and politics, the Turkish halal market still remains marginal within the national economy. Among a number of complex economic and cultural factors, one reason is that the early Republican regime established the national economy based on secular ideology managed by state-run enterprises alongside private companies between the 1930s and 1980s. Previously, halal certification was not the main concern of state or private business initiatives. During the 2000s, halal regulatory bodies for-profit began to emerge one after another. The halal 
market is not driven by the Turkish state's aggressive bureaucratization and strict regulations. Embracing the dominant neoliberal discourse of limited state intervention, the AKP government endorses decentralization and promotes the relative absence of the state in the halal market. Since fields are "relational configurations where change in one position shifts the boundaries among all other positions" (Swartz, 1997: 124), the lack of state intervention into the halal market change the rules and landscape of the Turkish halal market field by providing an ambiguous position and relative autonomy to the $\mathrm{HCls}$. For instance, $\mathrm{HCls}$ have emerged in a field in which the Turkish state provides a significant extension of powers granted to $\mathrm{HCls}$ by loosely regulating the halal market in Turkey. The AKP government, in parallel to its neoliberal tenets, constraint its capacity to implement a longterm centralized program for the adjustment of the halal market. By promoting decentralization and private companies, the Turkish state facilitated the power struggles among HCls. However, the lack of state support for a newly emerging market came with a price. Due to underdeveloped nature of the Turkish halal market, the Islamic actors have little prospect of achieving international competitiveness and success. The power struggle for making and controlling of a new field operates in the national level. As a result, $\mathrm{HCls}$ utilize diverse discursive strategies to flourish, to occupy a power position, and to legitimize their existence in the halal market field. The ambivalent structure of the Turkish halal market, shaped by the lenient state regulations including the deregulation principal of neoliberal ideology, has foregrounded private $\mathrm{HCls}$ by providing them privileges to occupy a power position. The Turkish halal market has been formed and characterized by the contesting discursive formations within these power struggles which create a compelling, yet a contradictory emergent field. 


\section{References}

Ab Talib, Mohamed Syazwan, Tahoo Ai Chin and John Fischer (2017), "Linking Halal Food Certification and Business Performance", British Food Journal, 119 (7),1606-18. https://doi.org/10.1108/BFJ-012017-0019

Akyol, Mevlüt and Özgür Kılınç (2014), "Internet and Halal Tourism $\begin{array}{llll}\text { Marketing", } \quad \text { Turkish Studies, } 9 & \text { (8), } & \text { 171-86. }\end{array}$ https://doi.org/10.7827/TurkishStudies

Alıç, Selahaddin (2016), "Başlarken", Helal Denetim, (accessed on December 7, 2015), [available at: www.helaldenetim.com].

Alkol Konusunda Fetva (2015), Helal Der, (accessed on December 7, 2015), [available

http://www.helalder.org.tr/SayfaListe.aspx?sayfaAdi=alinankararlarf etvalar\&url=alkol-konusunda-fetva].

Atalan-Helicke, Nurcan (2015), "The Halal Paradox: Negotiating Identity, Religious Values, and Genetically Engineered Food in Turkey", Agriculture and Human Values, 32 (4), 663-74. https://doi.org/10.1007/s10460-015-9585-z

Bergeaud-Blacker, Florence (2016), "The Halal Certification Market in Europe and the World: A First Panorama", Halal Matters: Islam, Politics, and Markets in Global Perspective, Florence BergeaudBlacker, John Fischer $\mathrm{J}$ and JohnLever, eds. Oxon, OX and New York, NY: Routledge, 105-26.

Bergeaud-Blackler, Florence (2004), "Social Definitions of Halal Quality: The Case of Maghrebi Muslims in France", The Qualities of Food. Alternative Theories and Empirical Approaches, Mark Harvey, Andrew McMeekin and Alan Warde (eds), Manchester, UK: Manchester University Press, 94-107.

Bergeaud-Blacker, Florence, John Fischer and John Lever (2016), Halal Matters: Islam, Politics, and Markets in Global Perspective, Oxon, OX and New York: Routledge.

Benson, Rodney (1998), "Field Theory in Comparative Context: A New Paradigm for Media Studies", Theory and Society, 28 (1), 463-98. https://doi.org/10.1023/A:1006982529917

Bourdieu, Pierre and Loic J.D. Wacquant (1992), An Invitation to Reflexive Sociology, Chicago: The University of Chicago Press.

Bourdieu, Pierre (2003 [1972]), Outline of a Theory of Practice, Cambridge, UK: Cambridge University Press. 
Bourdieu, Pierre (1983), "The Field of Cultural Production or The Economic World Reversed", Poetics, 12, 311-56. https://doi.org/10.1016/0304422X(83)90012-8

------, Pierre (1984), Distinction: A Social Critique of the Judgement of Taste, London, UK: Routledge.

Bourdieu, Pierre (1989), "Social Space and Symbolic Power", Sociological Theory, 7, 14-25. https://doi.rog/10.2307/202060

-------, Pierre (2005), The Social Structures of the Economy, Cambridge, UK: Polity.

Canniford, Robin and Eminegul Karababa (2013), "Partly Primitive: Discursive Constructions of the Domestic Surfer", Consumption, $\begin{array}{llll}\text { Markets and } \quad \text { Culture, } 16 & \text { (2), } & 119-44 .\end{array}$ https://doi.org/10.1080/10253866.2012.662818

Dahlberg Lincoln and Sean Phelan (2013), Discourse Theory and Critical Media Politics, New York, NY: Palgrave Macmillan.

De Nooy, Wouter (2003), "Fields and Networks: Correspondence Analysis and Social Network Analysis in the Framework of Field Theory", Poetics, $31 \quad$ (5-6), 305-27. https://doi.org/10.1016/S0304422X(03)00035-4

Fischer, John (2009), "The Other Side of the Logo: The Global Halal Market in London", The New Cultures of Food: Marketing Opportunities from Ethnic, Religious, Cultural Diversity, Adam Lindgreen and Marin K. Hingley eds., Surrey Farnham, UK and Burlington, VT: Gower, 7388.

-------, John (2011), The Halal Frontier: Muslim Consumers in a Globalized Market, New York, NY: Palgrave MacMillan.

GIMDES, (2015a), "GIMDES'ten Alkolsüz Şarap ve Bira Açıklaması", (accessed on May 28, 2015), [available at: https://www.haberler.com/GiMDES-ten-alkolsuz-sarap-ve-biraaciklamasi-7176680-haberi/].

-------, (2015b), Halal Certification, Gimdes, (accessed on December 19, 2015), [available at: http://www.halalcertificationturkey.com/en/ourmission/].

, (2015c), Halal ve Tayyib Workshop Program, Gimdes, (accessed on October 21, 2015), [available at: http://www.halalcertificationturkey.com/en/2015/09/GiMDES-halaland-tayyib-workshops-program/].

(2015d), Gimdes İcin Destek Cagrisi, Gimdes, (accessed on October 30, 2015), [available at: http://www.GIMDES.org/GiMDES-icindestek-cagrisi]. 
Gimdes (2015e), "Helal Şampanya”, Şerefsizler Görev Başında: Gimdes, (accessed on August 11 2015), [available at: http://www.GiMDES.org/serefsizler-gorev-basinda-helal-sampanya4.html].

Göle, Nilufer (1997), "The Quest for the Islamic-self within the Context of Modernity", Rethinking Modernity and National Identity in Turkey, Sibel Bozdogan and Resat Kasaba eds., Seattle, USA and London, UK: University of Washington Press, 91-94.

Gülalp, Haluk (1997), "Modernization Policies and Islamic Politics in Turkey," Rethinking Modernity and National Identity in Turkey. Sibel Bozdogan and Resat Kasaba eds., Seattle, USA and London, UK: University of Washington Press, 52-63.

HEDEM (2015), "Icerik", Helal Denetim, (accessed on August 3, 2015), [available at: http://www.helaldenetim.com/icerik.aspx].

Halal Certification Turkey (2015), "Our Mission", Halal Certification Turkey, (accessed on September 12, 2015), [available at: http://www.halalcertificationturkey.com/en/our-mission/].

Helal Denetim (2015), Icerik, Helal Denetim, (accessed December 19 2015), [available at http://www.helaldenetim.com/icerik.aspx].

Helal Denetim (2016), "Icerik", Helal Denetim, (accessed on April 7, 2015), [available at: http://www.helaldenetim.com/icerik.aspx].

Helalder Kurumsal (2015), "Kurumsal”, Helal Der, (accessed on August 11 2015), [available at: http://www.helalder.org.tr/kurumsal.asp?id=1\&helalder=Hakk\%C4\% B1m\%C4\%B1zda].

Ziauddin, Sharmeen (2013), "Halal Wine Anyone?", Huffington Post, (accessed on September 28, 2019), [available at: https://www.huffingtonpost.co.uk/sharmeen-ziauddin/halalwine b 4171528.html?guccounter=1\&guce referrer=aHR0cHM6Ly 93d3cuZ29vZ2xILmNvbS8\&guce referrer sig=AQAAAKh9JBRy4N 1LSsaNHAFAmCSeAB7IOL9nZhQxDAxoeRMb3N1wTfJ4dsoPATM 05nZGsx7MsgWFRQsPYOJdbTExK1jlyO7Z4yQEX8zC0aR8EEps2BwhlPSslanfUJzCSxr68MczqLBgbLi6Wfciv9GuwG8W1eh QZs5t0e JcpyKay8

Izberk-Bilgin, Elif and Cheryl C. Nakata (2016), "A New Look at Faith-based Marketing: The Global Halal Market", Business Horizons, 59 (3), 28592. https://doi.org/10.1016/..bushor.2016.01.005

(2012), "Theology meets the Market Place: The Discursive Formation of the Halal Market in Turkey," Spirituality and Consumption, Diego Rinallo, Linda Scott and Pauline Maclara eds., London, UK: Routledge, 41-53. 
Kaptan, Yeşim and Gökçen Karanfil (2013), "RTÜK, Broadcasting, and the Middle East: Regulating the Transnational", International Journal of Communication, 7 (2013), 2322-40.

Lever, John and Haluk Anil (2016), "From an Implicit to an Explicit Understanding: New Definitions of Halal in Turkey", Halal Matters: Islam, Politics, and Markets in Global Perspective, Florence Bergeaud-Blacker, John Fischer $\mathrm{J}$ and JohnLever, eds. Oxon, OX and New York, NY: Routledge, 38-54.

Milliyet (2015), "Kadehleri Helal Sarap ve Sampanya Dolduruyor", (accessed on October 23, 2015), [available at: http://www.milliyet.com.tr/Ekonomi/HaberDetay.aspx?aType=Haber DetayArsiv\&ArticlelD=1090200\&Kategori=ekonomi\&b=Kadehleri,\% 20helal\%20Sarap\%20ve\%20sampanya\%20dolduruyor].

Navaro-Yashin, Yael (2002a), Faces of the State: Secularism and Public Life in Turkey, Princeton and Oxford, NJ: Princeton University Press.

Navaro-Yashin, Yael (2002b), "The Market for Identities: Secularism, Islamism, Commodities," Fragments of Culture: The everyday of Modern Turkey, Deniz Kandiyoti and Ayse Saktanber eds., New Brunswick NJ: Rutgers University Press, 221-53.

Öniş, Ziya (1998), State and Market. The Political Economy of Turkey in Comparative Perspective, Istanbul, Turkey: Bogazici University Press.

Sabah (2011), "Rusvetle Halal Sertifikasi", Sabah Journal, (accessed on September 20, 2015), [available at: http://www.sabah.com.tr/ekonomi/2011/12/09/rusvetle-helalsertifikasi].

Sandıkçı, Özlem and Guliz Ger (2001), "Fundamental Fashions: the Cultural Politics of the Turban and the Levi's", Advances in Consumer Research, Mary C. Gilly and Joan Meyers-Levy, eds., Valdosta, GA: Association for Consumer Research, 146-50.

--------- and -------- (2007), "Constructing and Representing the Islamic Consumer in Turkey", Fashion Theory 11, 189-210. https://doi.org/10.2752/136270407X202754.

Swartz, David (1997), Culture and Power: The Sociology of Pierre Bourdieu, Chicago, IL: University of Chicago Press.

Swartz, David L (2016), Bourdieu's Concept of Field, Oxford: Oxford University Press.

Thomson, Patricia (2014), Field, Pierre Bourdieu: Key Concepts, in Grenfell M. ed, London, UK and New York, NY: Routledge, 65-80.

Üstüner, Tuba and Craig J. Thompson (2012), "How Marketplace Performances Produce Interdependent Status Games and 
Contested Forms of Symbolic Capital", Journal of Consumer Research 38 (5), 796-814. https://doi.org/10.1086-660815

Wodak, Ruth (2001), "What CDA is about- A Summary of its History, Important Concepts and its Development", Methods of Critical Discourse Analysis, Ruth Wodak and Michael Meyer eds, London, UK: Sage.

Yener, Dursun (2015), "Factors that affect the Attitudes of Consumers Toward Halal-Certified Products in Turkey", Journal of Food Products Marketing $21 \quad$ (2), 160-78. https://doi.org/10.1080/10454446.2013.843483 